\title{
In the face of epistemic injustices?: on the meaning of people-led war crimes tribunals
}

\author{
Mark Boyle \\ National Institute for Regional and Spatial Analysis, Department of Geography, National \\ University of Ireland Maynooth, County Kildare, Ireland; e-mail: mark.g.boyle@nuim.ie \\ Received 10 February 2014; in revised form 30 December 2014 \\ Audrey Kobayashi \\ Department of Geography, Queens University, Kingston, Ontario, Canada; \\ e-mail: kobayasi@queensu.ca
}

\begin{abstract}
This paper seeks to render intelligible the meaning of the vibrant tradition of people-led war crimes tribunals (PWCTs) which has emerged in the past half a century. Drawing upon recent postcolonial critiques of extant literature on geographies of care and responsibility, and informed by Third World Approaches to International Law (TWAIL), we question the capacity of the international legal system to provide justice for 'others' (especially subaltern and colonised communities) at a distance. We situate PWCTs in the context of the claim that the international legal system is systemically contaminated because it is conceptually Western. We interrogate the seminal Russell Tribunal on Vietnam (1966-67) and in so doing are led to place under scrutiny the postcolonial and dialectical ethics which characterised the work of French philosopher, literary giant, and political activist Jean-Paul Sartre before, during, and after his tenure as Executive President of this tribunal. We argue that insofar as PWCTs speak subaltern truth to power, they work to decentre the Western ethical, legal, and juridical canon and confront insidious epistemic injustices. We conclude that any search for a postcolonial ethics to guide caring from afar can both inform and be informed by PWCTs.
\end{abstract}

Keywords: Jean-Paul Sartre, people-led war crimes tribunals, Russell Tribunal, postcolonial geography, law, ethics, Vietnam

\section{Introduction}

In the shadow of the rise to prominence of officially sanctioned international war crimes tribunals (IWCTs), there has arisen in the past half century a parallel and alternative tradition of dissident people-led war crimes tribunals (PWCTs). This paper enquires into the sense which is to be made of PWCTs - their intelligibility, meaning, and significance. We construe PWCTs as public tribunals convened by concerned citizens who attempt to care for others at a distance (often profoundly marginalised, colonised, and subaltern communities) by taking responsibility for their right to seek justice in circumstances in which this right is violated with impunity. Casting PWCTs thus invites consideration of the extent to which such tribunals might speak to and in turn be informed by literature on geographies of care and responsibility. We are interested in bringing PWCTs into conversation with recent postcolonial interventions in this literature which unveil the Western centricity of many ideas about caring and acting responsibly and which call for a new postcolonial ethics to guide caring from afar.

Existing literature largely locates PWCTs in the context of the claim that the international legal system is systemically compromised because it is pro-Western by geopolitical fiat. This analytical register is not without merit but it does tend to assume it is geopolitics only and not international law also which constitutes a problem. PWCTs enter the historical stage in response to perceived pathologies inherent in the official system of IWCTs. Their mission is to ensure that everyone is treated equally in the eyes of the law, including its authors. Our starting 
point in contrast is Third World Approaches to International Law (TWAIL), which call attention to relationships between social power, epistemology, and juridical logic. We situate PWCTs in the context of the deeper claim that the international legal system is systemically contaminated because it is conceptually Western. Here doubt is cast on the adequacy of international law as currently constituted ever to serve as an adequate guarantor of justice for distant others.

At the heart of this argument is the claim that there exists a fundamental incommensurability between international law and subaltern ethics (although see Jeffrey and Jakala, 2013). Given life under conditions of colonial and neocolonial violence, at the core of subaltern ethics is the belief that the violence, killing, and torture visited on colons by the dispossessed is freighted with its own unique morality. Accordingly, subaltern ethics often lead to radically other adjudications in relation to issues such as the rights of citizens rather than states to assume sovereign authority over the means of violence; the right of dissidents to possess and use nonconventional weapons; the right of states to recruit spies and to practice shoot-to-kill policies; the right of vigilantes to police their own communities and to dispense justice during times of war (or peace for that matter); the right of prisoners to be given political status and to be released early as part of peace processes; the right of civilians to appropriate the property of others if it serves the purposes of a political cause; the right of police informers and whistleblowers; the right of indicted 'on the runs' to return to homelands without facing trials; and the right of victims of violence to seek compensation and redress. It is not our intention to venerate such adjudications. Nor do we advocate ethical relativism. We find indefensible and reprehensible many actions and inactions in subaltern juridical systems just as we find abhorrent certain presences and absences in the international legal system. But we do want to argue that in order to care that justice is served to others at a distance it is necessary to question whether 'our' justice is seen by 'others' as a just justice and to entertain the idea that there exist radically other traditions of ethics, justice, and law. Certainly this insight has proven central to the success of many reconciliation and peace processes.

Notwithstanding their dissident credentials, on the basis of their entanglements with international law, we place under investigation the extent to which PWCTs might be construed as conceptually estranged from the moral registers of those whose rights they claim to uphold. Our investigation turns on an interrogation of the seminal Russell Tribunal on Vietnam (1966-67) and on Jean-Paul Sartre's writings on ethics before, during, and after his tenure as Tribunal Executive President. We argue that it would be a mistake to read PWCTs as simple extensions of international law enabling colonised and subaltern peoples to seek justice within terms set by colonising and capitalist hegemons. Insofar as they conspire to provincialise the Western canon, PWCTs in fact serve as historically novel instruments through which concerned citizens can speak subaltern moral and legal truth to power, both in and beyond this canon. Of course this is not to obfuscate the dissonances between the organisers of such tribunals and those they claim to speak for, a topic worthy of future study. Nevertheless, we conclude that any search for a postcolonial ethics to guide caring from afar can both inform and be informed by PWCTs.

The paper has three sections. After this introduction section 2 interrogates relationships between social power, epistemology, and juridical logic, arguing that insofar as PWCTs present themselves as better guardians of international law than the international legal community itself, they must be placed under scrutiny as adequate mechanisms for seeking justice for others at a distance. Section 3 provides a detailed reading of the Russell Tribunal on Vietnam, arguing that the architects of this tribunal wrestled not only with their belief that the international community was applying international law in a duplicitous manner, but also with the Western centricity of the ethical, legal, and juridical precepts upon which international law is built. These struggles invite reconsideration of the intelligibility of this tribunal. In section 4 we explore Jean-Paul Sartre's writings on ethics, law, and anticolonial 
violence. Sartre's novel dialectical ethics, we contend, not only yields insight into the ways in which he conceived and crafted the Russell Tribunal on Vietnam; it also provides a basis from which PWCTs more generally might be recast as a 'more than Western' modality for seeking justice for those dwelling afar. We conclude that any search for a postcolonial ethics to guide caring from afar can both inform and be informed by PWCTs.

\section{Caring from afar, international law, and epistemic injustices}

Literature on geographies of care and responsibility makes the case that place-specific imperatives to care from afar arise because of historically ingrained and tenacious powerladen and asymmetrical relationships and connectivities between places. But recent postcolonial interventions insist that such 'power geometries of relational space' also situate, condition, and colour many endeavours (however well meaning) to right past wrongs. The international legal system provides a critical infrastructure through which to seek to care for distant others by taking responsibility for their rights to protection, justice, and legal redress in circumstances in which such rights are violated. But given that it has been colonial and neocolonial powers that have conceived, authored, built, and now govern over international law, it is pertinent to enquire into the limitations of routing caring from a distance through 'official' ethical, legal, and juridical frameworks.

The principle which holds that better resourced countries in the Global North bear a general responsibility for the well-being of comparatively more impoverished countries in the Global South has seemingly been eschewed in favour of a new emphasis upon relationality and the uneven spatial development of political responsibility. Given the interdependencies and interconnections among the peoples of the world today, it is necessary to approach places as relational rather than as bounded entities. Because they exist as relational entities and specifically as nodes in hierarchical networks, each place owes it to the other places to which it is connected to take responsibility for its footprint and to act ethically towards specific others at a distance (Massey, 2004). Only by cultivating a 'global sense of place' (Massey 1991) might hegemonic places gain an elevated awareness of their particular responsibilities within the network, to promote peaceable and enriching relations between peoples and places based upon principles of reciprocity, mutuality, and relationality rather than exploitation, dependency, and extraction.

But a number of postcolonial scholars focusing on care and responsibility have questioned the extent to which conceptions of responsibility and care emanating from the Global North might be said to be Western-centric. Whilst insisting that power laden and asymmetrical relationships and connectivities between places do carry with them geographically variegated obligations to take responsibility for distant others and to act more ethically towards those others, such scholars also foreground the need to historicise understandings of care and responsibility. They argue that countries in the Global South have a right to contest and to refuse claims of responsible leadership and forms of caring which remain foreign to their own registers. Lawson (2007) emphasises the need to provincialise concepts of care so that especially parochial and partisan concepts do not become hegemonic. Noxolo et al (2012) claim that geographical writings on responsibility need to attend both to relationality (that which connects places) and to estrangement (that which sets places apart). They disrupt assumptions of distance by suggesting that geographical imaginings remain open to refusal, rejection, and contestation (see also Madge et al, 2009; Raghuram 2009; Raghuram et al, 2009). Nowhere in the geographical literature has it been more forcefully stated than in Gregory's (1995; 2012) claim that imaginary distances between 'us' and 'them', by reifying and stretching distance, create the material conditions of warfare and political domination.

This debate finds resonance in controversies surrounding the building of an international legal system and in particular the mobilisation of IWCTs. The past century has witnessed 
sustained efforts to build an international legal system capable of prosecuting leaders who abuse their offices by committing high crimes such as crimes against peace and crimes of aggression, war crimes, crimes against humanity, and genocide (Bassiouni, 2011; Crowe 2014; Smith, 2012). The origins of the specific instrument of the IWCT can be traced to the World War 2 Nuremberg trials (1945-46) and Tokyo War Crimes Tribunal (1946). Whilst IWCTs were put into hibernation during the Cold War period they have enjoyed accelerated development since the collapse of the Berlin Wall. The time-limited United Nations Tribunal on Yugoslavia (initiated in 1993) announced a new era for IWCTs, as did the time-limited United Nations Tribunal on Rwanda (UNTR, initiated in 1994), and the series of timelimited hybrid international-national criminal courts created in Sierra Leone, Cambodia, East Timor, Kosovo, and Bosnia between 1999 and 2001. The Rome Statute of the International Criminal Court (2002) and inauguration of the permanent International Criminal Court in The Hague stand as the apogee of the project.

Recent writings in the field of Critical Legal Studies, and in particular a branch of this field focusing on TWAIL contend that the genesis and mutation over time of international law has been inextricably wound up with the rise, reign, and faltering of Europe from the 16th century on [for an introduction to TWAIL see Anghie et al (2003), Balakrishnan (1998-99), Chimni (2011), Eslava and Pahuja (2011), Falk et al (2008), Gathii (1998; 2011), Grovogui (1996; 2006), Haskell (forthcoming), Mickelson (1998), Mutua (2000), Mickelson et al (2008), Mickelson (2008), Okafor (2008), Pahuja (2011)]. International law, writes Mutua (200, page 31)

" is illegitimate. It is a predatory system that legitimizes, reproduces and sustains the plunder and subordination of the Third World by the West. Neither universality nor its promise of global order and stability make international law a just, equitable, and legitimate code of global governance for the Third World."

Law has its origins in the European Enlightenment and is predicated upon Enlightenment ethical traditions and in particular Kantian deontology. The European colonial project was made possible only through extensive practices of inventing, warping, and applying judiciously legal frameworks of European parentage. Meanwhile, the West continues to rely on international law to serve its ongoing imperial, neocolonial, and hegemonic projects (Comaroff, 2001). For the West the rule of law has simply meant rule through law (Rajkovic, 2012). TWAIL then invites critical scrutiny of the potential of international law (at least in its current form) ever to secure justice for subaltern populations.

Fricker's $(1998 ; 2007)$ concept of 'epistemic injustices' highlights the social powerknowledge nexus that regulates normative regimes. Epistemic injustices can be defined as injustices caused by the inability of prevailing epistemic regimes to countenance the voices of those who know the world from alternative subject positions. Fricker identifies two kinds of epistemic injustices. Testimonial injustices arise when, often by stealth, insidious precognitive prejudices lead to a devaluing of the credibility and authority of certain witnesses to truth and therefore to the dismissal of the testimonies provided by these witnesses. Hermeneutical injustices, in contrast, arise when injured parties find themselves unable to give voice to or to challenge an ethical wrong because they lack a vocabulary for putting that wrong into social context. Given its nestedness inside complex histories of colonial and neocolonial subjugation, it is pertinent to place under scrutiny the specific testimonial and hermeneutic epistemic injustices which the international legal system perpetrate upon subaltern and colonised communities.

In the shadow of official endeavours to mobilise IWCTs there have arisen dissident traditions motivated by many and complex political, economic, technical, ideological, and cultural grievances. Our focus is on one such tradition, embodied in the vibrant genre of PWCTs which has emerged in the past half a century. These tribunals include the influential 
series of Russell Tribunals [on Vietnam (1966-67), Chile's military coup (1974-76), human rights abuses in psychiatry (2001), human rights abuses in Latin America (2003), the war on Iraq (2004), and on the plight of the Palestinian people and Palestinian state (2008-2014)]; the International Tribunal on Crimes against Women (1976); the Permanent People's Tribunal established in 1979 and concluded in 1983 in Madrid, which examined war crimes in the Western Sahara and Eritrea and made pronouncements on the Armenian genocide; the Indian Independent People's Tribunal on the World Bank Group (2008); the Peoples' International Climate Justice Tribunal (2009); and the Kuala Lumpur War Crimes Tribunal on Iraq (2011). Although bearing no officially recognised legal authority and lacking in juridical force, citizen-led tribunals have often resulted in high-profile (for the most part Western) leaders being publicly execrated as international criminals, fuelling popular outrage and activism (Cuadrado-Quesada and Simm, 2014; Kampmark, 2014).

Given their radical and dissident roots, it is tempting to approach PWCTs as a potential 'solution' to paternalistic Eurocentric gestures which aspire to care for distant others but which in fact subvert subaltern ethics. But to what extent might PWCTs prove helpful in providing a new postcolonial departure point for advancing the project of caring from afar? Alas, to date PWCTs have been rendered principally in terms of an analytical register which has framed their significances in terms of their consonance (or not) with Western canons of ethics, justice, and law. PWCTs often present themselves as better stewards of the Western legal tradition than is the West itself, emerging when there is a perceived indefensible reluctance within the 'international community' to apply law universally and to prosecute with equal vigour the leaders of advanced Western capitalist polities. The West acts duplicitously when it holds others to standards it itself does not feel bound to live by. PWCTs insist on the indissolubility of the principle that no one is above the law and everyone ought to be treated equally in the eyes of the law. Of course detractors dismiss PWCTs as little more than 'kangaroo courts', 'show trials', and 'theatrical charades' convened by ideologues bent on condemning the West before hearing evidence. In conception, design, and execution they fail to live up to virtually every accepted legal standard. Even when being dismissed, Western juridical norms are the essential standard.

But we argue that it would be a mistake to read PWCTs as simple extensions of international law enabling colonised and subaltern peoples to seek justice within terms set by colonising and capitalist hegemons. We seek here to position these tribunals as a historically novel form of justice seeking which transcends Western ethical, legal, and juridical logics. PWCTs certainly present themselves as better stewards of Enlightenment ethics and international law than the architects of the official international legal system. The duplicity of the West, which invokes, convenes, and mobilises international law when geopolitically convenient but which refuses to be bound by the same law itself, has to be unveiled. But by giving renewed credibility to subaltern testimonies which otherwise might go ignored and by providing profound and articulate renditions of why colonial violence constitutes the primordial ethical wrong, PWCTs confront epistemic injustices and rupture hegemonic epistemic regimes. Recasting PWCTs as both in and beyond Western canons of ethics, justice, and law permits an exploration of their potential to serve as an instrument through which to seek a just justice for those wronged by colonial and neocolonial subjugations.

\section{The intelligibility of the Russell Tribunal on Vietnam 1966-67}

The roots of United States aggression towards Vietnam, Cambodia, and Laos lie in the rise and fall of the French colonial adventure in Indochina. In 1954, following a protracted war between France and its allies and the Soviet and Chinese-backed Vietnam national independence movement led by Ho Chi Minh (the Viet Minh), France granted independence to Vietnam, Cambodia, and Laos. Recognising political differences between North Vietnam 
and South Vietnam, the Geneva conference of 1954 divided Vietnam at the 17th parallel: North Vietnam, renamed the Democratic Republic of Vietnam (DRV), was to be governed by the Viet Minh from Hanoi; South Vietnam, renamed simply the State of Vietnam, was to be governed by the pro-Western Ngo Dinh Diem from Saigon. Reunification was to come following national elections in 1956. These elections were never held.

The Vietnam War emerged out of this vacuum. The Vietnam People's Army (the North Vietnamese Army) in partnership with the Viet Cong (National Liberation Front, a South Vietnamese guerrilla force directed by the North), and communist allies (particularly the Soviet Union, China, North Korea, and Cuba) fought for a unified Vietnam under communist rule. These groups viewed partition as a neocolonial strategy pursued by the West against the Indochina region. Meanwhile the South Vietnamese army, in collaboration with Western allies (in particular the United States, but also Australia, Japan, Thailand, and the Philippines), fought for an independent South Vietnam organised around liberal capitalist and democratic principles. These groups viewed partition as at once a necessary defence of a minority population and an essential brake on the Global march of communism. By 1973 United States military personnel withdrew from the conflict; by 1975 the Vietnamese People's Army gained control of Saigon; and in 1976 a unified Socialist Republic of Vietnam was declared.

Against the backdrop of growing disquiet among concerned citizens over US military intervention in Indochina, the Russell Tribunal on Vietnam was convened by the British philosopher, mathematician, and public activist Bertrand Russell in 1966 and organised and chaired by the French philosopher, author, and activist Jean-Paul Sartre across three sessions held between 1966 and 1967. Its purpose was to call to account the United States and its allies for breaches of international law committed in the region. The aims of the tribunal were agreed upon at a 'Constituting Session' held in London on 15 November 1966. The purpose of the tribunal was to reach verdicts on five key questions:

1. Has the United States Government (and the Governments of Australia, New Zealand, and South Korea) committed acts of aggression according to international law?

2. Has the American army made use of or experimented with new weapons or weapons forbidden by the laws of war?

3. Has there been bombardment of targets of a purely civilian character, for example hospitals, schools, sanatoria, or dams, and on what scale has this occurred?

4. Have Vietnamese prisoners been subjected to inhuman treatment forbidden by the laws of war and, in particular, to torture or mutilation? Have there been unjustified reprisals against the civilian population, in particular, execution of hostages?

5. Have forced labour camps been created, has there been deportation of the population or other acts tending to the extermination of the population and which can be characterised juridically as acts of genocide?

A Tribunal Committee comprising twenty-five distinguished 'citizen jurors' from eighteen countries collected testimonies from more than thirty witnesses over two sittings, the first in Stockholm from 2 to 10 May 1967, the second in Roskilde from 20 November to 1 December. Included were British journalist Tariq Ali, British philosopher A J Ayer, African-American novelist James Baldwin, Italian lawyer and politician Lelio Basso, former Mexican president Lázaro Cárdenas, General Secretary of the British National Union of Mineworkers Lawrence Daly, French feminist Simone de Beauvoir, American pacifist David Dellinger, Jewish activist Haika Grossman, Filipino Poet Laureate Amado V Hernandez, Chair of the Cuban Committee for Solidarity with Viet Nam Melba Hernandez, and playwright, author, and film director Peter Weiss. Final verdicts were reached at the conclusion of the Roskilde meeting (figure 1).The Tribunal Report was finally published in 1971 (Russell Vietnam War Crimes Tribunal, 1971). ${ }^{(1)}$

(1) The Proceedings of the Tribunal are held at Cornell University, and the contents are accessible electronically at: http://rmc.library.cornell.edu/EAD/htmldocs/RMM04285.html 
Has the Government of the United States committed acts of aggression against Vietnam under the terms of international law?

Yes (unanimously).

Has there been, and if so, on what scale, bombardment of purely civilian targets, for example, hospitals, schools, medical establishments, dams, etc?

Yes (unanimously).

We find the government and armed forces of the United States are guilty of the deliberate, systematic and large-scale bombardment of civilian targets, including civilian populations, dwellings, villages, dams, dikes, medical establishments, leper colonies, schools, churches, pagodas, historical and cultural monuments.

We also find unanimously, with one abstention, that the government of the United States of America is guilty of repeated violations of the sovereignty, neutrality and territorial integrity of Cambodia, that it is guilty of attacks against the civilian population of a certain number of Cambodian towns and villages.

Have the governments of Australia, New Zealand and South Korea been accomplices of the United States in the aggression against Vietnam in violation of international law?

Yes (unanimously).

The question also arises as to whether or not the governments of Thailand and other countries have become accomplices to acts of aggression or other crimes against Vietnam and its populations. We have not been able to study this question during the present session. We intend to examine at the next session legal aspects of the problem and to seek proofs of any incriminating facts.

Is the Government of Thailand guilty of complicity in the aggression committed by the United States Government against Vietnam?

Yes (unanimously).

Is the Government of the Philippines guilty of complicity in the aggression committed by the United States Government against Vietnam?

Yes (unanimously).

Is the Government of Japan guilty of complicity in the aggression committed by the United States Government against Vietnam?

Yes (by 8 Votes to 3. The three Tribunal members who voted against agree that the Japanese Government gives considerable aid to the Government of the United States, but do not agree on its complicity in the crime of aggression.)

Has the United States Government committed aggression against the people of Laos, according to the definition provided by international law?

Yes (unanimously).

Have the armed forces of the United States used or experimented with weapons prohibited by the laws of war?

Yes (unanimously).

Have prisoners of war captured by the armed forces of the United States been subjected to treatment prohibited by the laws of war?

Yes (unanimously).

Have the armed forces of the United States subjected the civilian population to inhuman treatment prohibited by international law?

Yes (unanimously).

Is the United States Government guilty of genocide against the people of Vietnam? Yes (unanimously)

Figure 1. Verdict of the Russell Tribunal. 
It is not possible in a paper of this length to discuss in full the range of voices articulated in the diverse 'testimonials' of violence and atrocities offered by Western and Vietnamese observers [but see Andersson's (2011) very useful bibliographic essay on the tribunal, Russell's own collection of essays War Crimes in Vietnam (1967), and Falk's four-volume The Vietnam War and International Law (1968; 1969; 1972; 1976) where the Russell testimony (and much more testimony regarding Vietnam) is analysed in terms of different legal and ethical positions]. Here, and with reference to the voices of Russell and Sartre, we simply want to document the coexistence throughout the tribunal of two seemingly incommensurable logics; one which pitted the tribunal as in and of the international legal system, the other which vigorously and unapologetically celebrated its departure from Western norms and protocols.

Opening the tribunal, Russell invoked the spectre of Justice Robert H Jackson, Chief Prosecutor at the Nuremberg War Crimes Trials, who famously pronounced:

"If certain acts and violations of treaties are crimes, they are crimes whether the United States does them or whether Germany does them. We are not prepared to lay down a rule of criminal conduct against others which we would not be willing to have invoked against us" (Russell, 1971, page 1).

The approach was to note the existence of a fragile and skeletal international legal framework through which war tribunals might be convened (pointing in particular to the Nuremberg Trials), and to contend that the failure to call such a tribunal in the case of the Vietnam War constituted a deafening silence, explained only through reference to the colonial and neocolonial strategies of the US. International law was built and mobilised when it suited the West; when it did not it was sidelined, frustrated, rendered mute.

Members of the Tribunal Committee claimed that the tribunal was searching only for the truth and therefore was fair, transparent, neutral, and objective. In his Inaugural Statement in Stockholm in 1967, for instance, Sartre turned the unofficial status of the trial into an asset:

"We are powerless: that is the guarantee of our independence. ... There is nothing to help us except for the participation of the supporting committees which are, like ourselves, meetings of private individuals. As we do not represent any government or party, we cannot receive orders. We will examine the facts in our souls and our consciences, as we say, or, if one prefers, in the full liberty of our spirits" (1971, page 4).

Witnesses from all sides were entitled to attend and make submissions, be cross-examined, and have their testimonies transcribed for the record. In an interview with Sartre published by the New Left Review in its Jan-Feb 1967 issue, he was challenged: "You will be asked by what legal right, since it is the law which you are invoking, you are setting yourselves up as judges, which you are not." In his response Sartre noted that the tribunal ran the risk of embodying either "petit bourgeois idealism" or "partisan fascism", but insisted that its purpose was simply to "apply to capitalist imperialism its own laws" (Sartre, 1967, page 8).

The tribunal was from the outset pervaded by formal legalistic discourse and presented itself as a paragon of established legal canons. For instance, Sartre's Summary and Verdict of the Stockholm Session in May 1967 traced the findings of the Tribunal to the KelloggBriand Pact of 1928; Article 2 of the United Nations Convention; Article 6 of the Statute of Nuremberg, The Geneva Agreements of 20 and 21 July 1954; the United Nations resolution of December 1960; The Hague Convention No. 4 of 18 October 1907, and in particular Articles 22, 25, and 27 of this Convention; and the Geneva Convention of 2 August 1949, in particular Articles 18 and 53. Moreover, Sartre's Statement On Genocide, delivered at the final session in Roskilde in November 1967, presented a forensic and legalistic interrogation of the meaning of the term 'genocide' and an assessment of the degree to which the United States and its allies could be said to be practising genocide as defined by Article 2 of the United Nations Convention On the Prevention and Punishment of the Crime of Genocide (1948) (see also Sartre, 1983). 
But many critics, including Western politicians, supporters, and especially the media, dismissed the tribunal as a self-appointed 'kangaroo court', biased from the outset and searching only for findings which might build a case against the South Vietnamese and the United States and its allies. Its architects were "cynical and ridiculous" (Time 19 May 1967, quoted in Kampmark, 2014, page 5); Sartre was "a long Communist crony" (Time 12 May 1967, quoted in Kampmark, 2014, page 5); and Russell's intellect was enfeebled by political naiveté, "an old man in a hurry", "who has left his judgment, his reputation and his usefulness behind" (Levin, 1967, quoted in Kampmark, 2014, page 5). According to an English journalist, "It will be like in Alice in Wonderland: there will be the sentence first, and the trial afterwards" (quoted in Sartre, 1967, page 1). Certainly, whilst presenting itself a virtuous guardian and steward of the Western legal paradigm, the tribunal made little effort to conceal the fact that it departed from established Western legal canons in a number of crucial ways.

It cannot be ignored that, always and everywhere, the context of the Vietnam war, and in particular its colonial and neocolonial origins, framed judgments as to the rights and wrongs of certain actions. It is especially crucial and noteworthy that the Russell Tribunal asserted that in no sense could crimes committed by a powerless victim facing the prospect of genocide be placed in the same ethical or legal category as crimes committed by an imperialist aggressor. In the same New Left Review interview referred to above, Sartre was further challenged: "Some people will reproach you for not judging the Vietnamese at the same time as the Americans, and will say that war crimes are committed by both sides." His reply: "I refuse to place in the same category the actions of an organization of poor peasants, hunted, obliged to maintain an iron discipline in their ranks, and those of an immense army backed up by a highly industrialized country of 200 million inhabitants" (Sartre, 1967, page 12). Likewise, consider Russell's presentation at the closing session in Stockholm in May 1967:

"Who would compare the 100,000 tons of napalm with a peasant holding a rifle? Who can fail to distinguish the power which destroys the hospitals and schools of an entire people from the defenders who attack the aeroplanes carrying napalm and steel fragmentation bombs?" (1967, page 2).

It cannot be ignored that the North Vietnamese played an important role in the creation of the tribunal (Mehta, 2012). In February 1966, for example, the Bertrand Russell Peace Foundation held talks in Hanoi with Ho Chi Minh and DRV Prime Minister Pham Van Dong which resulted in the North Vietnamese government providing funds, witnesses, and access in support of the tribunal. Russell also consulted London-based North Vietnamese journalists, including employees of the Hanoi-based Cuu Quoc (National Salvation) weekly journal, and London-based people's organizations of the DRV and the National Liberation Front of South Vietnam. It cannot be ignored that the Russell Tribunal comprised carefully chosen and partisan citizen jurors with prior declared political positions. It cannot be ignored that, whilst formal and legalistic in places, witness accounts and submissions and summations by Committee members were often intemperate in tone and at times shot through with visceral anger.

Given the anomalies which exist between the architecture of the tribunal and established norms in international law, we submit that to reduce the Russell War Tribunal on Vietnam to an exercise in holding the US and its allies to their own standards is to overlook its deeper significance. The ambiguous attitude of the Tribunal Committee to political violence, we submit, is fundamentally revealing. Whilst critics sought to dismiss this attitude as inconsistent, duplicitous, and ultimately a core failing, we argue that it betrays a more profound ethical and legal conundrum. The Tribunal Committee struggled with the proposition that the search for an international legal system and a global judiciary overseeing crimes committed by political and military leaders is elusive precisely because Western ethical precepts underpin law and 
therefore law in its very constitution is ill equipped to adjudicate in the colonial present. The legitimacy of the adjudications in regard to such dilemmas stems less from their consonance with and adherence to a priori and universal ethical and legal frameworks, protocols, and practices and more from their alignment with historicised 'logics' of ethics, justice, and law birthed in the context of the dialectical interplay between colonial violence and anticolonial resistance. This key observation pervaded the tribunal but was for the most part implicit and rarely consciously articulated or ruminated upon. But it was central to the thought of Sartre before, during, and after his tenure as Executive President.

\section{Sartre, ethics, and violence: towards a geohistory of ethical paradigms}

Sartre is perhaps best known for his philosophical work Being and Nothingness (first published in 1943), which continues to stand as the definitive outline of existentialism. But in his later years, Sartre dedicated both his philosophical and his substantive writings and activism to a single end: he was motivated principally to develop a Marxist theory that would be capable of rescuing Marxism from its tyrannical, fossilised, and crystalline degeneration under Stalin in the Soviet Union. Sartre's thinking developed against the emergence of a new tradition of Western Marxism that might loosely be termed French existential Marxism (Poster, 1975) and sought to place alienation and its transcendence as the primary motive force in history. French existential Marxists believed that Marx's historical teleology was correct but that the transition to a socialist society was not hard-wired into capitalism's economic contradictions. They sought to put existentialism to work to build a more agency-centred Marxism and developed insights into the anthropology of the social and political movements that would change the world. The Critique of Dialectical Reason, published in bundles from the mid1950s to the early 1960s (hereinafter to be referred to as the Critique), was to be Sartre's principal contribution to this project.

It is well beyond the scope of this paper to provide an in-depth discussion of the Sartrean dialectic (probably his most important philosophical contribution), but a brief note is required to inform what follows. For Sartre, human freedom requires human beings to continually make themselves anew, but human existence is marked by a constant fight against alienation. In most societies resources are limited relative to human need, and in the scramble for finite matter humans lose themselves in complex systems of production, distribution, and consumption. They objectify others as threats to their access to resource pools and in turn become objectified themselves. The human capacity for autonomous selfproduction is misdirected, and instead praxis is dedicated to the (re)production of iniquitous systems of profit and stifling bureaucracies - or what Sartre calls the 'practico-inert'. Trapped in fossilised practico-inert structures, human beings lapse into inert 'massified groups' or 'serialised groups'. In the present context the chief manifestations of such structures are racism, class oppression, patriarchy, colonialism, and capitalism.

Whilst paralysing and debilitating, human alienation serves as a progenitor of the dialectic that drives history forward. Revolutionary movements emerge from seriality, motivated by the goal of transcending alienation and recovering an 'integral humanity'. In their embryonic forms these movements manifest themselves as spontaneous and anarchic 'groups in fusion'. Struggling to emancipate themselves, groups in fusion coalesce, aggregate, and tend towards a universal history (a socialist society). But this drift towards totalisation is far from predetermined. Groups in fusion most often spiral off following their own contingent, creolised, and anarchic trajectories. Many abort, degenerate, and deform before reaching their destination. With stakes in the revolutionary process, complex revolutionary bureaucracies confuse means with ends and conspire to create new forms of human alienation, masses, and groups in series. There is no totalisation to history then. Marxism's eschatology and linear teleology are replaced by a series of circular histories based on the complex ways in which 
revolutionary movements gain life, galvanise revolutionary energy, ossify into crippling monstrosities themselves, and finally are toppled by second-generation revolutionary groups who make them their objects.

In searching for a Sartrean ethics, some scholars turn first to his unfinished Notebooks for an Ethics (1992 [1983]), a series of writings penned between 1945 and 1948 but not published until after his death (Linsenberd, 2000). But this text remains so provisional, fragmented, and inconclusive that it is difficult to extract from it anything like a coherent Sartrean ethics. We find ourselves in agreement with those who prefer to search for Sartre's views on ethics throughout his corpus of writings (Jeanson, 1981; Sze, 2010). To this end Flynn (1994) has classified Sartre's ethics as developing through three phases: his ethics of authenticity, his dialectical ethics, and his final ethics of fraternity. The chronological unfolding of these phases has generated considerable debate. Some claim that Sartre's existentialist ethics of authenticity is incommensurable with his later Marxist dialectical ethics. We side with those who see continuity in Sartre's thinking and view the latter as an elaboration of the former by a now more politically conscious Sartre (eg, Anderson, 1991; 1993; Bell, 1989; Detmer, 1986). Meanwhile many commentators scoff at the authenticity of Sartre's seemingly neardeath 'conversion' to Messianic Judaism and his final commitment to an ethics of fraternity [published as Hope Now (Sartre and Levy, 1995)]. We indeed read Sartre's final ethics of fraternity as incongruous with his prior writings and for the present purposes bracket it from further consideration (see also Crittendon, 2009).

Sartre famously ended Being and Nothingness with a commitment to write an existentialist theory of ethics, a commitment he was never fully to fulfill. Sartre defined this mission as a search for 'ethics after God'. Sartrean existentialism implies that to act ethically is to act authentically, to exercise one's freedom. To act in bad faith, to serve as a being for others, is to act unethically. Immediately, however, a problem presents itself; it makes little sense to suggest that all acts, even if they oppress others, including through violence and terror, are ethical if they are authentic. In Existentialism and Humanism Sartre (1948, page 18) attempted to resolve this inevitable conclusion by claiming that he was "obliged to will the liberty of others at the same time as mine. I cannot make liberty my aim unless I make that of others equally my aim." In other words, the pursuit of authenticity is never ethical if it impairs the ability of others likewise to practise an authentic existence (see Bell, 1989; Santoni, 1995; Taylor, 1991).

By the time he came to write the Critique, Sartre $(1976 ; 1991)$ had undergone a transition, from a philosopher of human freedom to an activist intellectual concerned with social and political critique and action. A central theme in Sartre's later writings is the idea that human praxis is always and everywhere dialectical, spatial, geographically situated, and constituent of actual human history (see Boyle and Kobayashi, 2011; Kobayashi and Boyle, 2014). Sartre sought to extend this insight by casting ethics as human praxis (theory in action) in given historical and geographical conditions. As he wrote the Critique Sartre came to realise that his underdeveloped existential ethics of authenticity was unfit to cope with the political realities of the 20th century and steadily began to develop a new dialectical ethics or socialist ethics. Three key manuscripts written between 1964 and 1966 were to seal this transition: his famous Rome Lecture (1964), his unfinished Sartre's Morale (1964), and his Recherches pour une Morale, known as the Cornell Lecture (which Sartre never delivered in protest over the US bombing of North Vietnam) (Stone and Bowman, 1986; 1991).

It is perhaps with respect to anticolonial violence that Sartre's dialectical ethics were to find greatest expression. Sartre was drawn to the problem of colonialism, convinced that colonisation, rebellion, and resistance heralded a profoundly significant moment in the unfolding of human history. Anticolonial struggles were the only true heirs of authentic Marxism; only in the colonies might the genuine historical potential of Marxism be fulfilled. 
According to some, Sartre's attitude to anticolonial violence reached its zenith in his famous 1961 preface to Fanon's Wretched of the Earth, which continues to stand as his most brutal and controversial statement on the necessity for anticolonial movements to embrace violence as part of their struggle. It is here that Fanon's influence on Sartre's thinking on violence is presumed to come to a head. For the Sartre of this preface, violence was a necessary antidote to colonial oppression, a means of securing freedom and redeeming the lost humanity of the oppressed. But this preface fails to capture the complexity of his views at the time, and it has to be remembered that Sartre's writing was part of a fiery public discussion in the heat of decolonisation. As a consequence, he was perhaps less than measured in his rhetoric (Caze La, 2007; Santoni, 2003).

Arguably it was in his 1964 Rome Lecture that he presented his most careful and considered ideas on ethics. In the lecture Sartre introduced the idea of 'socialist ethics' (Crittendon, 2009). An ethical society was a society in which humans were free to make themselves. Because this freedom was only possible in a socialist society, socialist societies were the only ones capable of supporting such an ethics. The central ethical conundrum in the interim was how to birth a revolutionary movement capable of pushing history towards a classless socialist society using means which were morally defensible. Returning to his formulation of the circular dialectic, because revolutionary movements continue to dwell in worlds organised in response to material scarcity, Sartre argued that these movements often themselves degenerate into oppressive and terrorising fraternities, parties, organisations, and bureaucracies. Revolutionary means can be considered moral only if they are consistent with revolutionary ends. Accordingly, a number of limited and provisional or 'alienated moralities' (presocialist ethical regimes which dwell in conditions of oppression) were rendered necessary.

For Sartre four such alienated moralities were of particular importance (Stone and Bowman, 1986). The job of each was to reflexively police and marshal revolutionary movements so that they might avoid spiralling into oppressive instruments and going awry. It is here that Sartre moved beyond relativism and insisted on the need to temper and delimit anticolonial violence. Firstly, since revolutionary movements often misunderstand their mission and attempt to return oppressed societies to primordial pasts which were equally oppressive, it was the job of ethics to resist the temptation to institute past affairs as natural. Secondly, since revolutionary movements often worship their leaders and reify their organisational structures (parties, fraternities, organisations) as ends in themselves, it was the job of ethics to temper the excesses of these organisational structures and to resist the drift towards idolatry. Thirdly, since revolutionary movements were often required to use violence, it was the duty of ethics to ensure that anticolonial violence did not degenerate into mindless terror. For Sartre (a) violence itself should be applied only 'provisionally' and should not itself become a settled norm; (b) violence should not lead to an 'ideology of terror' and an atmosphere of intimidation; (c) violence should be pursued only if other more peaceable forms of resistance were blocked; and (d) violence was legitimate only if it issued from the will of the people. Finally, since the destination for each revolutionary movement might be different, it was the duty of ethics to temper the enthusiasm of early revolutions to impose their outcomes on later revolutions.

Sartre, we argue, approaches ethics as historically emergent and therefore nonfoundational. But crucially he refuses to elide nonfoundational ethics with ethical relativism. Sartre has clear ideas about what might constitute a moral world; his socialist ethics lead him to hope for a world in which human beings transcend alienation and become products of their own labour. Sartre's rooting of ethics in a circular historical dialectic helps explain why he could never put on the same plane the violence perpetrated by colonising and neocolonial powers on the one hand and that enacted by marginalised, colonised, and subaltern anticolonial movements 
on the other. Moreover Sartre's concept of 'alienated moralities' points to his interest in the role of ethics in policing and correcting anticolonial movements so that revolutionary means are always aligned with revolutionary ends. Sartre's approach to ethics helps explain the troubled relationship the Russell Tribunal on Vietnam had with international law; it helps to account for the ways in which PWCTs can be said to be both in and beyond Western ethics, justice, and law; and it provides a starting point for addressing postcolonial critiques of the potential Western centricity of (otherwise well-meaning) endeavours to care from afar.

\section{Conclusion}

In this paper we have sought to bring into conversation recent postcolonial critiques of the Western centricity of many endeavours to care from afar with TWAIL, which claim that the international legal system is systemically contaminated because it is conceptually Western. Against this backdrop we have interrogated the extent to which PWCTs might prove helpful in advancing the project of caring from afar. Ensnared as they are in international law, PWCTs run the risk of being labelled yet further instances of (well-meaning) paternalistic Eurocentric gestures which aspire to care from a distance but which in the final analyses simply conspire to subvert subaltern ethics, law, and justice. But by charting the ways in which the seminal Russell Tribunal on Vietnam departed from established legal protocols and norms and by reading Sartre's conduct and speeches during the tribunal against his scattered but voluminous writing about ethics (and in particular his 1964 Rome Lecture), we have argued that PWCTs come pregnant with greater possibilities. Insofar as they conspire to provincialise the Western ethical, legal, and juridical canon, PWCTs serve as historically novel instruments through which dissident traditions attempt to speak subaltern moral and legal truth to power.

But how impactful are PWCTs in the final analysis? Numerous social histories attest to the importance of the Russell Tribunal on Vietnam in encouraging social activism, including the mobilisation of people on the streets by concerned citizens in the US and worldwide against the Vietnam War (eg, Hagan, 2001; Robbins, 2007; Tomes, 2000). Deploying Fricker's (1998; 2007) terminology, the tribunal undoubtedly confronted both testimonial and hermeneutic epistemic injustices and threatened and disoriented the hegemonic epistemic regime. It lent credibility and authority to voices which otherwise might have been discounted. It was heavily scripted and performed and the skill of that performance, including the persuasive rhetoric of tribunal organisers (especially Sartre), the dramatic backdrop of the European theatre, and the gravitas of those called to act as citizen jurors or serve as witnesses, all made it less easy to ignore. Moreover, the Russell Tribunal collected and presented voluminous pages of testimony documenting atrocities occurring on the ground, in the deltas, on the dikes, and in the fields of 1960s Vietnam. ${ }^{(2)}$ It generated a corpus of new hermeneutic resources which anticolonial movements (not least in Vietnam) and subsequent PWCTs have found useful in pressing home cases against colonial and neocolonial violence. But, alas, it would be a stretch to argue that it reset relationships between social power, epistemology, and juridical logic. We might conclude that the Russell Tribunal on Vietnam disturbed but did not result in a deep resetting of the dominant moral gestalt of the West.

We offer our discussion of Sartrean ethics as a contribution to the search for a decentred, nonfoundational and nonrelativist ethics to guide the project of caring from a distance. There exist strong resonances here with recent literature (although see de Beauvoir, 1948)

(2) Indeed, the French geographer Yves Lacoste provided evidence on the flooding that resulted from American bombing of the Mekong Delta (Bowd and Clayton, 2013). This evidence seems not to have been very important in the proceedings at the time, perhaps, ironically, because the members of the tribunal were so focused on the experiences of people that they paid scant attention to environmental degradation. 
on feminist, postcolonial, and subaltern ethics of care (see, for example, Gandi, 2014; Gilligan, 1982; Held, 1993; Nichols, 2010; Noddings, 1984; Tong and Williams, 2011; Tronto, 1993). Care ethics explicitly seeks to decentre established Enlightenment ethical frameworks, on the basis that these approaches to ethics are profoundly Cartesian, Western, masculinist, and limiting (Tong and Williams, 2011). Enlightenment ethics search for justice that is based on universal principles articulated abstractly by autonomous subjects, and prioritise cool detachment, valorise human reason, and advocate objective, neutral, and rational decision making. In contrast, care ethics begins with a social ontology of connection, foregrounding social relationships of mutuality and trust rather than dependence, where ethical judgments need to be made in the context of caring relationships. Care ethics prompts reflection on the limitations of routing caring from a distance through Western ethical, legal, and juridical frameworks, and underscores the value of locating questions of justice in the context of complex and charged relationships.

But care ethics has (largely without culpability) provoked the emergence of a distinction between humanitarian care (calibrated by justice ethics and practised by neutral, cool, and disembodied actors who apply universals to particulars) and intimate care (calibrated by care ethics and practised by engaged, emotional, and embodied actors who reach judgments in the context of complex relationships) (Barnett, 2005). In a series of recent publications, Barnett has questioned the merits of thinking about normative frameworks in terms of unhelpful dualisms (see, for example, Barnett, 2012). Of course, many ethicists now recognise the importance of bringing into conversation justice and care perspectives when arbitrating the virtues and vices of particular actions. They insist that both can be put to productive use, sometimes even with respect to a single problem. But Barnett seeks to go further; it is necessary, he argues, to move beyond dualist thinking tout court. Whilst advocates of humanitarian care turn to concepts of justice to validate particular actions and proponents of intimate care, to care ethics, Barnett holds open the possibility that there exists a modest, nonfoundational ethics and proposes that normative judgments are most often calibrated through situated and embodied reasoning or 'practical reason'.

We seek here to position PWCTs as a historically novel form of justice seeking which transcends the dualism between humanitarian caring and intimate caring from afar. We claim that PWCTs distinguish themselves from the Western ethical, legal, and juridical canon and align themselves with subaltern justice systems because they embody an approach to justice which is at once anti antifoundational and antirelativist. PWCTs are both constituted by and constitutive of ethical paradigms born of concrete historical and geographical circumstances. It matters that PWCTs enter the historical stage at a particular juncture in the dialectical interplay between colonial violence and anticolonial struggle. But this does not make their pronouncements any less moral, legal, or just. In spite of its claims to champion timeless and universal concepts of justice, international law, too, betrays historical and geographical roots in the European Enlightenment and plays to a politics of universality (Pahuja, 2011). But equally PWCTs do not license ethical relativism. Their legitimacy derives from the extent to which their practical or embodied reasoning appears compelling to, and gains traction over, situated actors entangled in complex relationships. For these reasons, we conclude that it makes sense to approach PWCTs as both of and beyond the Western paradigm.

\section{References}

Andersson S, 2011, "A secondary bibliography of the international war crimes tribunal: London, Stockholm and Roskilde" Russell: The Journal of Bertrand Russell Studies 31 167-187

Anderson T C, 1991, "Sartre's early ethics and the ontology of Being and Nothingness", in Sartre Alive Eds R Aronson, A van den Hoven (Wayne State University Press, Detroit, MI) pp 183-201

Anderson T C, 1993 Sartre's Two Ethics: From Authenticity to Integral Humanity (Open Court, Chicago, IL) 
Anghie A, Chimni B S, Mickelson K, Okafor O (Eds), 2003 The Third World and International Legal Order: Law, Politics and Globalization (Nijhoff, Leiden)

Balakrishnan R, 1998, "Locating the Third World in cultural geography" Third World Legal Studies $151-20$

Barnett C, 2005, “Who cares?”, in Introducing Human Geographies Eds P Cloke, M Crang, M Goodwin (Arnold, London) pp 588-601

Barnett C, 2012, "Geography and ethics: placing life in the space of reasons" Progress in Human Geography 36 379-388

Bassiouni M C, 2011 Crimes Against Humanity: Historical Evolution and Contemporary Application (Cambridge University Press, Cambridge)

Bell L A, 1989 Sartre's Ethics of Authenticity (University of Alabama Press, Tuscaloosa, AL)

Bowd G P, Clayton D W, 2013, "Geographical warfare in the tropics: Yves Lacoste and the Vietnam war" Annals of the Association of American Geographers 103 627-646

Boyle M, Kobayashi A, 2011, "Metropolitan anxieties: a critical appraisal of Sartre's theory of colonialism" Transactions of the Institute of British Geographers, New Series 42 158-177

Caze La M, 2007, "Sartre integrating ethics and politics: the case of terrorism" Parrhesia 3 43-54

Chimni B S, 2006, "Third World approaches to international law: a manifesto" International Community Law Review 8 3-25

Comaroff J L, 2001, "Colonialism, culture, and the law: a foreword" Law and Society Inquiry 305 $1-5$

Crittenden P, 2009 Sartre in Search of an Ethics (Cambridge Scholars Publishing, Newcastle Upon Tyne)

Crowe D, 2014 Crimes, Genocide, and Justice: A Global History (Palgrave Macmillan, New York)

Cuadrado-Quesada A, Simm G, 2014, "Peoples tribunals: a progressive mechanism to achieve justice" Human Rights Defender 23 21-23

de Beauvoir S, 1948 The Ethics of Ambiguity translated by B Frechtman. (Citadel Press, New York)

Detmer D, 1988 Freedom as a Value: A Critique of the Ethical Theory of Jean-Paul Sartre (Open Court, La Salle, IL)

Eslava L, Pahuja S, 2011, "Between resistance and reform: TWAIL and the universality of international law" Trade, Law and Development 3 103-130

Falk R A, 1968 The Vietnam War and International Law (Princeton University Press, California)

Falk R A, 1969 The Vietnam War and International Law, Volume 2 (Princeton University Press, Princeton, NJ)

Falk R A, 1972 The Vietnam War and International Law Volume 3 (Princeton University Press, Princeton, NJ)

Falk R A, 1976 The Vietnam War and International Law Volume 4 (Princeton University Press, Princeton, NJ)

Falk R, Stevens J, Rajagopal B (Eds), 2008 International Law and the Third World: Reshaping Justice (Routledge, New York)

Fricker M, 1998, "Rational authority and social power: towards a truly social epistemology" Proceedings of the Aristotelian Society, New Series 98 159-177

Fricker M, 2007 Epistemic Injustice; Power and the Ethics of Knowing (Cambridge University Press, Cambridge)

Gandi L, 2014 Common Cause: Postcolonial Ethics and the Practice of Democracy, 1900-1955 (University of Chicago Press, Chicago, IL)

Gathii J T, 1998 "International law and Eurocentricity" European Journal of International Law 9 $184-211$

Gathii J T, 2011, "TWAIL: a brief history of its origins, its decentralized network, and a tentative bibliography" Trade Law and Development $326-48$

Gilligan C, 1982 In a Different Voice: Psychological Theory and Women's Development (Harvard University Press, Cambridge, MA)

Gregory D, 1995, "Imaginative geographies" Progress in Human Geography 19 447-485

Gregory D, 2004 The Colonial Present: Afghanistan, Palestine, and Iraq (Blackwell, Malden, MA)

Grovogui S N, 1996 Sovereigns, Quasi Sovereigns, and Africans: Race and Self-determination in International Law (University of Minnesota Press, Minnesota, MN) 
Grovogui S N, 2006 Beyond Eurocentrism and Anarchy: Memories of International Order and Institutions (Palgrave Macmillan, London)

Hagan J, 2001 Northern Passage: American Vietnam War Resisters in Canada (Harvard University Press, Cambridge, MA)

Haskell J D, forthcoming, "The Twail Paradox Financial and Mercantile Law Review", volume 1

Held V, 1993 Feminist Morality: Transforming Culture, Society, and Politics (University of Chicago Press, Chicago, IL)

Jeanson F, 1981 Sartre and the Problem of Morality translated by R Stone (Indiana University Press, Bloomington, IN)

Jeffrey A, Jakala M, 2014, "The hybrid legal geographies of a war crimes court" Annals of the Association of American Geographers 104 652-667

Kampmark B, 2014, “Citizens' war crimes' tribunals” Social Alternatives 33 5-10

Kobayashi A, Boyle M, 2014, "Colonizing colonized: Sartre and Fanon", in Theorizing Anti-racism: Rethinking the Tensions Between Marxism and Critical Race Theory Eds A Bakan, E Dua (University of Toronto Press, Toronto) pp 184-204

Lawson V, 2007, "Geographies of care and responsibility" Annals of the Association of American Geographers 97 1-11

Linsenberd G E, 2000 An Investigation of Jean Paul Sartre's Posthumously Published Notebooks for an Ethics (The Edwin Mellen Press, Lewiston, NY)

Madge C, Raghuram P, Noxolo P, 2009. "Engaged pedagogy and responsibility: a postcolonial analysis of international students" Geoforum 40 34-45

Massey D, 1991, "A global sense of place” Marxism Today 38 24-29

Massey D, 2004, "Geographies of responsibility" Geografiska Annaler: Series B 86 5-18

Mehta H C, 2012, "North Vietnam's informal diplomacy with Bertrand Russell: peace activism and the international war crimes tribunal" Peace and Change 37 64-94

Mickelson K, 1998, "Rhetoric and rage: Third World voices in international legal discourse" Wisconsin International Law Journal 16 353-419

Mickelson K, 2008, “Taking stock of TWAIL histories" International Community Law Review 10 $355-378$

Mutua M, 2000, "What is TWAIL?" American Society of International Law Proceedings 94 31-40

Mickelson K, Odumosu I, Parmar P (Eds), 2008, "Situating Third World approaches to international law (TWAIL): inspirations, challenges and possibilities" International Community Law Review $1015-28$

Nichols T, 2010, "Speaking justice, performing reconciliation: twin challenges for a postcolonial ethics critical studies in improvisation" Etudes critiques en improvisation 6 1-15

Noddings N, 1984 Caring: A Feminine Approach to Ethics and Moral Education (University of California Press, Berkeley, CA)

Noxolo P, Raghuram P, Madge C, 2012, "Unsettling responsibility: postcolonial interventions" Transactions of the Institute of British Geographers, New Series 37 418-429

Okafor O, 2008, "Critical Third World approaches to international law (TWAIL): theory, methodology, or both?" International Community Law Review 10 371-378

Pahuja S, 2011 Decolonising International Law: Development, Economic Growth and: The Politics of Universality (Cambridge University Press, Cambridge)

Raghuram P, Madge C, Noxolo P, 2009, "Rethinking responsibility and care for a postcolonial world" Geoforum 40 5-13

Rajkovic N M, 2012, "Global law and governmentality: reconceptualizing the 'rule of law' as rule 'through' law" European Journal of International Relations 18 29-52

Robbins M S, 2007 Against the Vietnam War: Writings by Activists (Rowman and Littlefield, Lanham, MD)

Russell B, 1967 War Crimes in Vietnam (Allen and Unwin, London)

Russell B, 1971, "Bertrand Russell speech to the first meeting of members of the war crimes tribunal", in Prevent the Crime of Silence: Reports from the Sessions of the International War Crimes Tribunal Founded by Bertrand Russell Eds P Limqueco, P Weiss (Allen Lane, London) pp 1-3 
Russell Vietnam War Crimes Tribunal, 1971 Prevent the Crime of Silence: Reports from the Sessions of the International War Crimes Tribunal Founded by Bertrand Russell Eds P Limqueco, P Weiss (Allen Lane, London)

Santoni R E, 2003 Sartre on Violence: Curiously Ambivalent (Pennsylvania State University Press, University Park, PA)

Sartre J-P, 1943 Being and Nothingness: An Essay on Phenomenological Ontology (Routledge, London)

Sartre J-P, 1948 Existentialism Is a Humanism (Methuen, London)

Sartre J-P, 1967, "Imperialist morality" New Left Review 41 3-32

Sartre J-P, 1971, "Inaugural statement: Stockholm meeting", in Prevent the Crime of Silence: Reports from the Sessions of the International War Crimes Tribunal Founded by Bertrand Russell Eds P Limqueco, P Weiss (Allen Lane, London) pp 1-7

Sartre J-P, 1976 Critique of Dialectical Reason Volume 1: Theory of Practical Ensembles (New Left Books, London)

Sartre J-P, 1983, "Vietnam, imperialism, and genocide", in Between Existentialism and Marxism Ed. J-P Sartre (Verso, London) pp 67-83

Sartre J-P, 1991 Critique of Dialectical Reason, Volume 2: The Intelligibility of History (Verso, London)

Sartre J-P, 1992 [1983] Notebook for an Ethics translated by D Pellauer (University of Chicago Press, Chicago, IL)

Sartre J-P, Levy B, 1995 Hope Now: The 1980 Interviews translated by A van den Hoven (The University of Chicago Press, Chicago, IL)

Smith C A, 2012 The Rise and Fall of War Crimes Trials: From Charles I to Bush II (Cambridge University Press, Cambridge)

Stone R, Bowman E, 1986, "Dialectical ethics: a first look at Sartre's unpublished 1964 Rome lecture notes" Social Text 13-14 195-215

Stone R, Bowman E, 1991, "Sartre's 'Morality and History': a first look at the notes for the unpublished 1965 Cornell Lectures", in Sartre Alive Ed. R Aronson, translated by A van den Hoven (Wayne State University Press, Detroit, MI) pp 53-82

Sze J A M, 2010 Sartre and the Moral Limits of War and Terrorism (Routledge, London) Taylor C, 1991 The Ethics of Authenticity (Harvard University Press, Cambridge, MA)

Tomes R R, 2000 Apocalypse Then: American Intellectuals and the Vietnam War, 1954-1975 (New York University Press, New York)

Tong R, Williams N, 2011, "Feminist ethics", in The Stanford Encyclopedia of Philosophy Ed. E Zalta (The Metaphysics Research Lab, Stanford, CA)

Tronto J C, 1993 Moral Boundaries: A Political Argument for an Ethic of Care (Routledge, New York) 